rapidly the means of transit is being developed, and of accommodation multiplied, it is evident that for some years to come this popularity will continue to grow. These great advantages and attractiveness are due to physical configuration and climate.

As regards climate, the two points to be specially considered are the rainfall and temperature. Of these the most varied, and apparently the most capricious, is the rainfall, which alone imparts to the Highlands very great diversity in its climates.

An annual rainfall of forty inches may be taken as the limit separating the dry climates of the East from the wet climates of the West Highlands. If a line be drawn froin Perth to Cape Wrath, all parts of Scotland to the east of it have, roughly speaking, a rainfall not exceeding forty inches, whereas to westward of that line the annual rainfall exceeds that amount. Hence the Eastern Grampians, the Highlands between the Don and Moray Firth, and the Highlands of Eastern Perth, Eastern Inverness, Eastern Ross, Eastern Sutherland, and Caithness are characterised by climates which are comparatively dry, and therefore bracing.

A glance at the map will show that the whole of the Scottish Highlands is, with respect to the west-south-west winds, entirely unprotected by Ireland, and completely exposed to these vapour-laden winds of the Atlantic. Over the whole of Scotland to the south of the Forth and Clyde, which may be regarded as under the lee of Ireland, the average rainfali at no station exceeds 66 inches, with the single exception of Ettrick Pen Top, 2268 feet high, at which fourteen years' observations gave an annual average of $7 \mathrm{I}$ inches.

On the other band, the Highlands to the north of the Clyde are fully open to the west-south-west winds of the Atlantic, and there accordingly the late summer and autumnal rains set in early and with great copiousness. Over an extensive tract resting, as it were, on a base line stretching from Dunoon to Balquhidder, and extending north-westward to beyond Dunvegan, in Skye, the annual rainfall is at least 80 inches. In this extensive region the heaviest rainfalls, and therefore wettest climates are met with in situations either inclosed among mountains of rugged grandeur, such as the districts about Lochs Coruisk, Hourn, and Shiel, or up and over such plateaux as that whence rise the Tay, Leven, Orchy, Aray, and Falloch. The spot of largest rainfall in Scotland, so far as known, is near the head of Glencroe, situated between Lochs Fyne and Long, the mean annual amount there being 128 inches. Surrounding in a somewhat irregular manner this wet district, and stretching northward along the watershed, as far as Loch Assynt, is another region of twice the extent over which the rainfall is from 60 to 80 inches. Again, on the east of this region, and between it and the line marking an annual rainfall of 40 inches, is an extensive tract stretching as far as Cape Wrath, which has a rainfall from 40 to 60 inches annually, and the same rainfall is found in Western Sutherland, a large portion of Western Ross, the whole of the Hebrides, and all islands to the south, the surfaces of which rise to no great height above the sea.

Reference has been made to the shelter afforded by Ireland in imparting a drier climate to places situated to the east-north-east of it. The same principle is seen in the influence of Skye and the Hebrides in bringing about the comparatively dry climate of Western Ross and Sutherland, the rainfall of which is from $\mathrm{I} 5$ to 20 inches less annually than in similar situations south of Skye, but unprotected from the rain-bringing winds of the Atlantic. Indeed of all places in the west situated to the north of the Crinan Canal, Western Ross and Sutherland enjoy the driest, most bracing, and most desirable climates.

This district has besides an additional advantage, which it possesses along with Skye and Western Inverness-shire during the prevalence of rain-bringing winds from the east. In the east of Scotland the heaviest rains are brought by winds from the east, which are not unfrequently accompanied with a downfall of 2 or 3 inches, or even on rare occasions of 4 inches of rain in a day. The worst and most persistent of these winds, which cause, perhaps, the most disagreeable weather of these climates, owing to the mixture of cold drizzle and rain they bring with them, seldom deposit any rain over the west coast to the north of the Crinan Canal, and over the west of Perthshire. Indeed, on such occasions the weather in the west is almost always marvellously fine, and once enjoyed can never be forgotten, skies of the utmost purity, beauty, and softness, a brilliancy and warmth in the sunshine, a deliciousness in the air, and lights, colouring, and shades towards evening, of such infinite variety and beauty as perhaps no other climate can match.

As regards temperature, the great attraction of the climate of the Scottish Highlands is its comparative coolness, and this coolness becomes, of course, all the greater, the higher we ascend above the sea. As compared with London, the summer temperature of Braemar, for example, during the months of July, August, September, and October, is respectively $8^{\circ} \cdot 9,9^{\circ} \mathrm{O}, 9^{\circ} \mathrm{I}$, and $7^{\circ} 4$ lower. The evenings and the nights are proportionally colder than the days. This is the climate which is best adapted for active exercise on the hills and moors. The admirably bracing and other bygienic qualities of the air of places which have comparatively dry climates, and which are 700 feet and upwards above the sea, are everywhere recognised; and it is these qualities which give the upper districts of Deeside, Donside, and Speyside the finest summer climates anywhere to be found in the British islands, particularly for those whose systems require to be braced up for the work of the coming winter. No other district, at these heights and temperatures, which contribute so important an ingredient to the climatic conditions required, can be named, having at the same time accommodation necessary for the comfort of summer visitors, which has not a summer climate essentially wet. The climates of places 700 feet high and upwards in Wales, the Lake District, on the slopes of the Lead and Lowther Hills, and eminently the West Highlands, can only be described as wet in comparison with those of the upper districts of the Dee, Don, and Spey.

Many excellent summer climates, but of quite a different type, are to be found at somewhat lower levels. Among the best of these, omitting sea-side climates, may be named Pitlochrie, Blair Athol, Lairg, Banchory, Dunkeld, Crieff, and Inverleithen, together with Callander and Moffat, the last two, however, being decidedly wetter, The important point to be attended to in selecting summer quarters in the Scottish Highlands is the rainfall, which is really the element of weather on which differences of climate depend; and attention to this point is all the more necessary, since in not a few cases a dry climate and a wet climate are to be found at comparatively short distances from each other.

\section{ON "GETTING" COAL BY MEANS OF CAUSTIC LIME}

THE operation of "getting" or breaking down coal from its original position in a seam cannot, in some cases, be effected with a sufficient degree of economy without the aid of blasting. But a certain amount of risk always attends the use of explosive substances, when they are employed for this purpose in fiery mines which are at the same time dry and dusty, unless certain precautions are taken which do not yet appear to be either generally observed or enforced by law. The existence of this danger has long been known, although its causes are only now beginning to be understood; and inventors have 
been trying to discover some other method of arriving at the same end without producing flame.

Amongst these may be.mentioned in this place :-

I. Improvements in wedging processes. A long iron wedge, placed in a previously drilled bore-hole between two strips of iron with flat faces and convex backs, is forced inwards by means of a sarew or by hydraulic pressure.

2. Improvements in blasting processes. (a) A gun powder cartridge is placed in an ordinary bore-hole, but a cylinder filled with water occupies most of the remainder of the hole instead of the usual tamping of rubbish (MacNab's Patent). (b) A dynamite cartridge inclosed in a waterproof bag is placed in the interior of the water cylinder of the last case (Abel's modification).

(The writer conducted a long series of experiments with dynamite water-cartridges for Prof. Abel and the Commissioners on Accidents in Mines, and the results will doubtless be published for the benefit of other investigators. In these experiments the mouth of the shothole was always situated in the centre of one side of a cubical bag containing 64 cubic feet of explosive gas.)

3. The caustic lime process, which forms the principal subject of the present note.

Although the proposal to employ caustic lime in this manner is not quite new, its first successful application has been made by Messrs. Smith and Moore, at Shipley Collieries in Derbyshire, where, thanks to the courtesy of these gentlemen, we lately saw it in operation under the superintendence of one of them. The seam of coal which is known as the Derbyshire Deep Hard, consists of three beds in immediate contact with each other. The top bed -one foot thick - is of inferior quality, and is left for a roof and permanently lost. The middle bed -2 feet 10 inches thick-produces good marketable coal in large blocks, and constitutes the object of working. The bottom bed-7 inches thick-together with a bed of soft shale Io inches thick, serves as a holing. The method of working is longwall-the faces being straight, and each about 100 yards long. The holing is carried in to a depth of about $3 \frac{1}{2}$ or 4 feet under the roal ; and while it is being done, the front of the mass which it is intended to detach is supported upon short timber props (sprags) placed at distances of six feet apart.

After the holing is completed a series of horizontal holes three inches in diameter are drilled close to the roof to a depth of three feet or so. These holes are also about six feet apart. Seven cylindrical blocks of caustic lime, each $2 \frac{1}{2}$ inches in diameter by $4 \frac{1}{4}$ inches long are placed in each hole. They are prepared by grinding burnt lime to a fowder, and then compressing it into blocks of the required shape and dimensions under a hydraulic press. They are, naturally, kept and carried in air-tight boxes. There is a groove in each block parallel with its axis, and large enough to receive a pipe $\frac{1}{2}$ inch in diameter. The grooves are kept uppermost in the bore-hole. An iron pipe $\frac{1}{2}$ inch in diameter, a few inches longer than the length of the hole, provided with a stop-cock at its outer end, and with a cloth bag drawn over its inner end, is inserted into the groove of the first block and then forms a guide for the others. Outside the last block the hole is firmly tamped first with paper, and then with rubbish.

After all the holes have been charged, a quantity of water, said to be equal in bulk to that of the caustic lime already occupying the hole, is forced into each in succession through the iron pipe. This is done by means of a hand-pump attached to a bucket, and provided with a short length of flexible hose. The stopcock of each pipe is immediately closed after the water has been introduced. This operation occupies about one minute for each hole, and the two men who carry it out pass along the face from one end to the other.

A sound as of steam escaping under a high pressure is now heard, and here and there the tamping is blown out.
Then follows the well-known sound of what is technically called "working "while the coal is being separated from the upper bed by the pressure of the expanding lime. After the lapse of a few minutes it is found that the whole mass of coal is resting upon the sprags, and these have only to be knocked out in order that it may fall in the face.

The time required for the various operations may be divided as follows :-Drilling, 12 minutes; charging, 4 minutes; introducing water, I minute; total, 17 minutes for each bore-hole.

Although this system is undoubtedly successful in the circumstances under which it has been applied, it would be a mistake to assume that it is likely to have anything but a limited application. For it has been found by experiment to be incapable of breaking down a hard rock or shale roof, such as is to be met wih in many mines in which blasting is required for that purpose, and for that alone.

Let us take the case of Risca Colliery, so notorious for great explosions, in which the roof of the roadways requires to be ripped down in order to get sufficient height for haulage purposes. The last great explosion took place at the beginning of the present year: but, as only the four men who were underground at the time were killed, it passed almost without remark. Nevertheless, the damage done by it was immense; coal-getting operations had to be suspended for over a month, and one large district of workings was entirely wrecked and was permanently abandoned.

And what were the circumstances under which all thi took place? Four men were firing four shots in the principal intake air-way in the presence of dry coal-dust. One of these shots blew out its tamping. The men were all found in the intake air-way with their safety-lamps uninjured.

This is a case which the objectors to the coal-dust theory both in this country and abroad would do well to ponder carefully.

William Galloway

\section{THE COLOURS OF FLOWERS, AS ILLUS- TRATED BY THE BRITISH FLORA}

I.

\section{General Law of Progressive Modification}

PETALS are in all probability originally enlarged and flattened stamens, which have been set apart for the special work of attracting insects. It seeins likely that all flowers at first consisted of the central organs alone - that is to say, of a pistil, which contains the ovary with its embryo seeds; and of a few stamens, which produce the pollen. But in those plants which took to fertilisation by means of insects-or, one ougbt rather to say, in those plants which insects took to visiting for the sake of their honey or pollen, and so unconsciously fertilisingthe flowers soon began to profuce an outer row of barren and specialised stamens, adapted by their size and colour for attracting the fertilising insects; and these barren and specialised stamens are what we commonly call petals.

As the stamens of almost all flowers, certainly of all the oldest and simplest flowers, are yellow, it would seem naturally to follow that the earliest petals would be yellow too. When the stamens of the outer row were flattened and broadened into peta's, there would be no particular reason why they should change their colour; and, in the absence of any good reason, they doubtless retained it as before. Indeed, the earliest and simplest types of existing flowers are almost always yellow, seldom white, and never blue; and this in itself would be sufficient ground for believing that yellow was the original colour of all petals. But as it is somewhat heretical to believe, contrary to the general run of existing scientific opinion, that petals are derived from flattened stamens, instead of from simplified and attenuated leaves, it may be well to detail here 